\section{Sandfly fauna in a military training area endemic for American tegumentary leishmaniasis in the Atlantic Rain Forest region of Pernambuco, Brazil}

\author{
Fauna de flebotomíneos em área \\ de treinamento militar endêmica para \\ leishmaniose tegumentar americana, \\ na Zona da Mata de Pernambuco, Brasil
}

\author{
Maria Sandra Andrade 1 \\ Hélio França Valença 2 \\ Amilton Lopes da Silva 2 \\ Francisco de Assis Almeida 2 \\ Ericka Lima Almeida ${ }^{3}$ \\ Maria Edileuza Felinto de Brito ${ }^{3}$ \\ Sinval Pinto Brandão Filho 3
}

In the Americas, the leishmaniases are zoonoses caused by various species of the genus Leishmania, sub-genera Viannia and Leishmania, transmitted by several sandfly species belonging to genus Lutzomyia (Diptera, Psychodidae), presenting two clinical forms referred to generically as American tegumentary leishmaniasis (ATL) and American visceral leishmaniasis (AVL) 1. ATL, like AVL, constitutes an important endemic disease in Brazil and elsewhere in the Americas, manifesting by different skin lesions, including single, multiple, and disseminated, the diffuse anergic cutaneous form, and the mucocutaneous form or "espundia", the most severe, causing serious and irreversible mutilations 2 . To date, some eleven sandfly species have been incriminated as ATL vectors in Brazil 1,3.

In the Northeast region of Brazil, ATL presents diverse eco-epidemiological characteristics, although with some intra-regional similarity. In the State of Bahia, studies in Três Braços, a cocoa-growing region with remnants of the primitive Atlantic Rain Forest, Lutzomyia whitmani is the vector involved 4 . In the State of Ceará, in the Baturité mountain range, L. whitmani is the principal vector 5, while L. migonei may be the secondary vector in peridomiciliary transmission and L. wellcomei is a possible vector for transmission in remaining forest areas 6,7.

In Pernambuco, ATL is currently incident in all regions of the State. The cases occur predominantly in the "Zona da Mata”, with more 
than $60.0 \%$ of the total reports ${ }^{8}$. Samples of Leishmania (Viannia) braziliensis were isolated from human patients and small wild and synanthropic mammals in a longitudinal study in the municipality (county) of Amaraji, in the southern Zona da Mata of the State, and L. whitmani is the predominant vector species 9,10,11.

In August 1996, an ATL outbreak occurred at the Marshall Newton Cavalcanti Military Training Camp (CIMNC), located in the municipality of Paudalho, in the northern Zona da Mata of Pernambuco, with 26 autochthonous cases reported among military men who had participated in training exercises. An epidemiological survey using the Montenegro skin test (MST) and an entomological survey at the site and in the troops who participated in the training activities showed an infection prevalence rate of $24.12 \%$. L. chot $i$ was the predominant vector, with $89.9 \%$ of the total sandfly fauna 12 .

From 1996 to 2003, 132 autochthonous case of ATL were reported at the CIMNC. Samples of $L$. (V.) braziliensis were isolated from patients and identified through reaction with a panel of specific monoclonal antibodies and enzyme electrophoresis profile 13. The current study presents findings on the identification and behavior of the sandfly fauna from July 2002 to June 2003, with the objective of characterizing the local population, contributing to better knowledge on the transmission of this endemic disease in the Atlantic Rain Forest region in Northeast Brazil.

\section{Material and methods}

The study was conducted at the CIMNC, located in the municipality of Paudalho, northern Zona da Mata, Pernambuco State, some $40 \mathrm{~km}$ from the State capital Recife (Figure 1). The CIMNC is a military facility founded in 1944 with the purpose of serving as military training grounds for the Brazilian Army. The total area is 6,280 hectares. The site, formerly part of a sugarcane plantation and mill, has a central command pavilion, two residential villas with 16 contiguous houses, a school, a chapel, 14 night watchmen's houses, eight barracks used for bunking troops during training, and six areas reserved for military training and exercises. The predominant vegetation consists of low-lying secondary forests, regional fruit trees like mango and jackfruit, and vast remnants of the original Atlantic Rain Forest. The mean annual temperature is $25^{\circ} \mathrm{C}$, with $85.0 \%$ mean relative humidity and some $280 \mathrm{~mm}$ monthly rainfall, with predominant peaks in April-June, with up to $500 \mathrm{~mm} / \mathrm{month}$. Information on the microclimate was obtained by monitoring the humidity and temperature on the sandfly capture days, while rainfall was recorded by the military facility itself during the study period.

Sandfly captures were conducted from July 2002 to June 2003 in areas used for daytime and nighttime military exercises in remnants of the Atlantic Rain Forest. The areas chosen as collection sites are characterized by the abundance of secondary forest and scattered regional fruit trees, and are located approximately $1.1 \mathrm{~km}$, $1.7 \mathrm{~km}, 2.0 \mathrm{~km}$, and $3.5 \mathrm{~km}$, respectively, from the facility's headquarters, and they are generally uniform.

Captures were conducted with six CDC light traps, installed from 18:00 to 6:00 hours, and manual captures using a Shannon trap from 18:00 to 21:00 hours during four consecutive nights per month, using one of the previously selected areas or sub-units each day. The light traps were positioned $10 \mathrm{~m}$ apart and some $100 \mathrm{~m}$ from the Shannon trap.

Manually captured specimens were stored in specific cages containing a small wad of cotton soaked in sugar solution, coved with plastic bags, and transported in the team's vehicle to a laboratory adapted in the military facility itself, where they were dissected and identified. Females were dissected in saline solution, observing the digestive tube to investigate natural infection. Specimens captured in the light traps and males captured manually were preserved in $70.0 \%$ alcohol, counted, and then prepared in Berlese solution 14 for identification, adopting the traditional systematics according to Young \& Duncan 15.

Flagellate forms found in dissected female sandfly specimens were inoculated in hamsters (Mesocricetus auratus) and agar blood base culture medium to attempt to isolate Leishmania 16. The cultures were examined every five days, aimed at confirming isolation of the parasite for subsequent species identification through reactions with a panel of species-specific monoclonal antibodies and isoenzyme electrophoresis profile 18,19 .

In the military training areas previously selected for sandfly captures, we also used 48 hamsters ( $M$. auratus) as sentinel animals in each monthly capture, during the 12-month period, with the objective of obtaining natural infection with Leishmania, aimed at subsequent parasite isolation and identification. A hamster was placed in a wire cage and exposed on each capture day from 08:00 to 06:00 hours the following morning. After the monthly capture work, the animals remained under obser- 


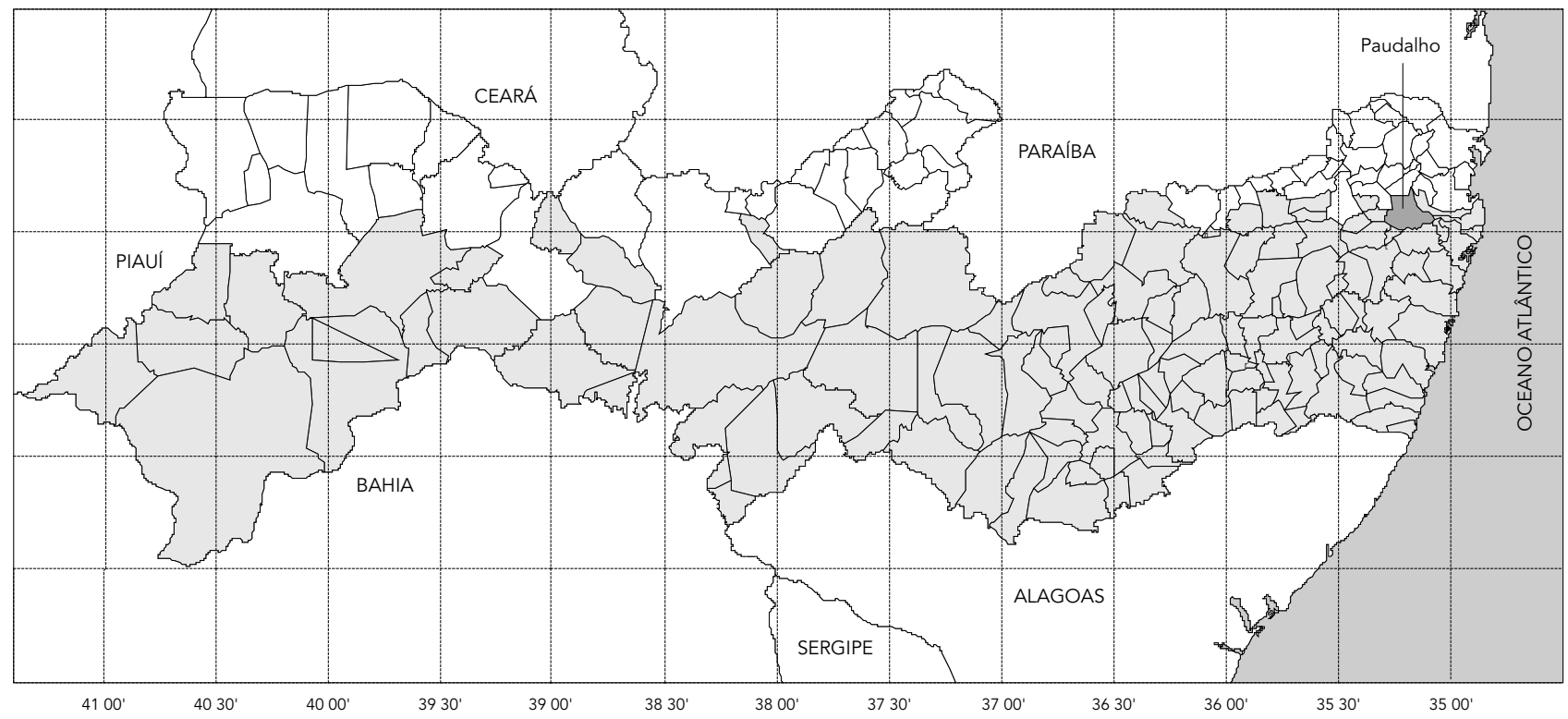

200

0

200

400 Kilometers

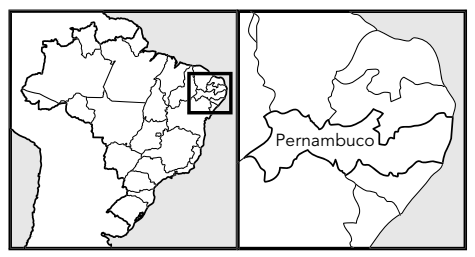

vation for a period of three to six months, monitored systematically for observation of clinical symptoms suggestive of infection, and after this period they were sacrificed to attempt to isolate Leishmania.

Data analysis and preparation of graphs used the Excel/Microsoft Office program.

\section{Results}

A total of 8,406 sandflies were captured, among which 16 species were identified (Table 1). $L$. complexa, with 4,317 (51.36\%) and L. choti, with 3,660 (43.54\%), were the most abundant species. In areas with primary forest remnants, 217 sandfly specimens were collected during three weeks of captures, with a predominance of $L$. choti $(55.76 \%)$ and L. complexa $(40.10 \%)$. Of the total captures, the male to female ratio was approximately $1: 2$. Considering only the total for L. complexa, the M:F ratio was approximately1:8, as compared to 1:1 for $L$. choti.

Considering the type of trap used, 6,984 $(83.08 \%)$ sandflies were captured with CDCmodel traps and 1,422 (16.92\%) with manual capture, with the aid of a Shannon trap (Table 2). Considering only manual capture with the aid of a Shannon trap, the predominant species was $L$. complexa, representing $80.10 \%$ of the total captures. The male:female ratio for this species in this type of capture was approximately 1:13.

A total of 912 females were dissected for detection of natural infection with Leishmania. 
Distribution of total sandfly species captured and identified at the Marshall Newton Cavalcanti Military Training Camp, Pernambuco State, Brazil, July 2002 to June 2003.

\begin{tabular}{|c|c|c|c|c|c|c|}
\hline \multirow[t]{2}{*}{ Species } & \multicolumn{2}{|c|}{ Males } & \multicolumn{2}{|c|}{ Females } & \multicolumn{2}{|c|}{ Total } \\
\hline & $\mathrm{n}$ & $\%$ & $\mathrm{n}$ & $\%$ & $\mathrm{n}$ & $\%$ \\
\hline L. complexa & 462 & 5.50 & 3,855 & 45.86 & 4,317 & 51.36 \\
\hline L. choti & 1,955 & 23.26 & 1,705 & 20.28 & 3,660 & 43.54 \\
\hline L. amazonensis & 52 & 0.62 & 143 & 1.70 & 195 & 2.32 \\
\hline L. longispina & 36 & 0.43 & 58 & 0.69 & 94 & 1.12 \\
\hline L. sordelli & 5 & 0.06 & 53 & 0.63 & 58 & 0.69 \\
\hline L. evandroi & 18 & 0.21 & 14 & 0.17 & 32 & 0.38 \\
\hline L. walkeri & 16 & 0.19 & 8 & 0.10 & 24 & 0.29 \\
\hline L. capixaba & 0 & 0.00 & 8 & 0.10 & 8 & 0.10 \\
\hline L. naftalekatzi & 2 & 0.02 & 4 & 0.05 & 6 & 0.07 \\
\hline L. schreiberi & 1 & 0.01 & 4 & 0.05 & 5 & 0.06 \\
\hline L. braziliensis & 0 & 0.00 & 2 & 0.02 & 2 & 0.02 \\
\hline L. quinquerfer & 0 & 0.00 & 1 & 0.01 & 1 & 0.01 \\
\hline L. tupynambaí & 0 & 0.00 & 1 & 0.01 & 1 & 0.01 \\
\hline L. whitmani & 0 & 0.00 & 1 & 0.01 & 1 & 0.01 \\
\hline L. barrettoi & 0 & 0.00 & 1 & 0.01 & 1 & 0.01 \\
\hline L. servulolimai & 1 & 0.01 & 0 & 0.00 & 1 & 0.01 \\
\hline Total & 2,548 & 30.31 & 5,858 & 69.69 & 8,406 & 100.00 \\
\hline
\end{tabular}

Table 2

Distribution of total sandfly species captured in CDC and Shannon traps at the Marshall Newton Cavalcanti Military Training Camp, Pernambuco State, Brazil, July 2002 to June 2003.

\begin{tabular}{|c|c|c|c|c|c|c|c|c|}
\hline \multirow[t]{4}{*}{ Species } & \multicolumn{8}{|c|}{ Type of capture } \\
\hline & \multicolumn{4}{|c|}{ CDC } & \multicolumn{4}{|c|}{ Manual/Shannon } \\
\hline & \multicolumn{2}{|c|}{ Males } & \multicolumn{2}{|c|}{ Females } & \multicolumn{2}{|c|}{ Males } & \multicolumn{2}{|c|}{ Females } \\
\hline & $\mathrm{n}$ & $\%$ & $\mathrm{n}$ & $\%$ & $\mathrm{n}$ & $\%$ & $\mathrm{n}$ & $\%$ \\
\hline L. complexa & 383 & 4.56 & 2,795 & 33.25 & 79 & 0.94 & 1,060 & 12.61 \\
\hline L. choti & 1,804 & 21.46 & 1,601 & 19.04 & 151 & 1.80 & 104 & 1.24 \\
\hline L. amazonensis & 49 & 0.58 & 137 & 1.63 & 3 & 0.04 & 6 & 0.07 \\
\hline L. longispina & 34 & 0.41 & 58 & 0.69 & 2 & 0.02 & 0 & 0.00 \\
\hline L. sordelli & 5 & 0.06 & 45 & 0.53 & 0 & 0.00 & 8 & 0.10 \\
\hline L. evandroi & 15 & 0.18 & 13 & 0.15 & 3 & 0.04 & 1 & 0.01 \\
\hline L. walkeri & 15 & 0.19 & 6 & 0.07 & 1 & 0.01 & 2 & 0.02 \\
\hline L. capixaba & 0 & 0.00 & 8 & 0.10 & 0 & 0.00 & 0 & 0.00 \\
\hline L. naftalekatzi & 1 & 0.01 & 4 & 0.05 & 1 & 0.01 & 0 & 0.00 \\
\hline L. schreiberi & 1 & 0.01 & 4 & 0.05 & 0 & 0.00 & 0 & 0.00 \\
\hline L. braziliensis & 0 & 0.00 & 2 & 0.02 & 0 & 0.00 & 0 & 0.00 \\
\hline L. quinquerfer & 0 & 0.00 & 0 & 0.00 & 0 & 0.00 & 1 & 0.01 \\
\hline L. tupynambaí & 0 & 0.00 & 1 & 0.01 & 0 & 0.00 & 0 & 0.00 \\
\hline L. whitmani & 0 & 0.00 & 1 & 0.01 & 0 & 0.00 & 0 & 0.00 \\
\hline L. barrettoi & 0 & 0.00 & 1 & 0.01 & 0 & 0.00 & 0 & 0.00 \\
\hline L. servulolimai & 1 & 0.01 & 0 & 0.00 & 0 & 0.00 & 0 & 0.00 \\
\hline Total & 2,308 & 27.47 & 4,676 & 55.61 & 240 & 2.86 & 1,182 & 14.00 \\
\hline
\end{tabular}


The dissected species and respective numbers were: L. complexa (462), L. choti (441), L. amazonensis (6), L. sordelli (2), and L. longispina (1). An isolation of flagellate forms characteristic of Leishmania was obtained in L. complexa captured in September in 2002, and inoculated in a hamster, but it was not possible to conduct typing due to contamination of the culture. The density of captured specimens showed the highest rate in the month of July 2002, including that of L. complexa, but the density rates for this species were also significant in the months of August 2002 and May 2003, periods in which the clinical cases were reported. The capture in June 2003 was jeopardized by the heavy and continuous rains during the capture period, with a rainfall of $477 \mathrm{~mm}$ during the month, the highest of the entire study period (Figure 2).

Isolation of characteristic Leishmania forms was obtained from the natural infection of one of the hamsters, but it was not possible to conduct typing for identification of the Leishmania species due to contamination of the sample in culture medium.

\section{Discussion}

L. (V.) braziliensis is the main etiological agent involved in ATL in Brazil and is also the most prevalent species, with geographic distribution in all regions of the country, whose eco-epidemiological characteristics and transmission mode are expressed according to each region's particularities. Most of the ecological-type epidemiological studies on ATL highlight the predominance of this endemic disease's zoonotic cycle in deforested areas with old settlements in Brazil, with vectors displaying peridomiciliary habits 20. Transmission in the CIMNC shows evidence of the maintenance of a sylvatic enzootic cycle, with the occurrence of periodic outbreaks following military training maneuvers in areas with forest remnants and secondary forests in the area.

The presence of 16 sandfly species in the CIMNC indicates an important diversity in the study area, with L. complexa as the most abundant species (51.36\%), followed by $L$. choti (43.54\%). L. choti was the most abundant species found in the survey conducted at the CIMNC in 1997 12. The relevant point here is the change in the diversity of fauna after this 56-year period. The preliminary study in 1997 showed the occurrence of eight species, of which L. wellcomei and L. ayrozai were not observed in the current study. L. complexa had not been found in this same area in the previ-
Figure 2

Monthly variation in sandfly population captured at the Marshall Newton Cavalcanti Military Training Camp over the period of one year.

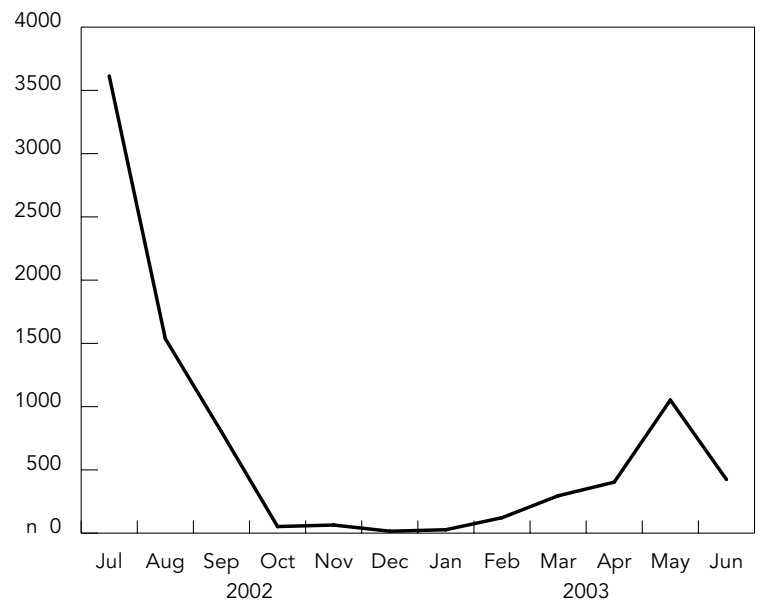

ous survey, although L. wellcomei, a sympatric species with L. complexa, was recorded. Isolation of the characteristically flagellate forms of Leishmania obtained in one specimen of $L$. complexa, as well as the observation that the disease cases are recorded predominantly after military training maneuvers during the months of July and August, the period in which the captures show an expressive predominance of $L$. complexa (87.00\%), constitute consistent indirect evidence identifying $L$. complexa as the principal suspected vector involved in transmission. A study in the Paragominas region, Pará State, identified four specimens of Psychodopygus complexus (= Lutzomyia complexa) naturally infected with $L$. (V.) braziliensis, demonstrating the importance of this species as a vector for L. braziliensis in the Amazon 21.

In the study in Amaraji, southern Zona da Mata, Pernambuco State, L. whitmani predominates in the local fauna 22 , with direct evidence incriminating it as the principal vector in the transmission of the zoonotic ATL cycle in the region, among other reasons based on the finding of natural infection with $L$. braziliensis (Brandão Filho SP, unpublished data). Nevertheless, in the remnants of the primitive Atlantic Rain Forest, similar to the situation found in the CIMNC, L. complexa was the most abundant sandfly in this ecotope 8,10 , where it is likely that maintenance of the enzootic sylvatic cycle of L. braziliensis involves wild mammals. 
The findings in this Paudalho area agree with our observations in the southern Zona da Mata of Pernambuco, reinforcing once again the contention that L. (V.) braziliensis is autochthonous to the Atlantic Rain Forest, contrary to the position that L. braziliensis is only autochthonous to the Amazon and that it was introduced later into the Atlantic Rainforest region through internal migratory processes 23 .

Resumo

Esse estudo teve como objetivo geral caracterizar a fauna de flebotomíneos envolvida em unidade de treinamento militar localizada na Zona da Mata do Estado de Pernambuco, Brasil, onde foram verificados casos humanos autóctones de leishmaniose tegumentar americana (LTA) associados a Leishmania (Viannia) braziliensis. A presença de 16 espécies de flebotomíneos no Centro de Instrução Militar Marechal Newton Cavalcanti indicou uma importante diversidade na área de estudo. Lutzomyia complexa constituiu a espécie mais abundante (51,36\%), seguida de L. choti (43,54\%). Todas as capturas foram realizadas nas áreas onde foram desenvolvidos treinamentos militares, nas quais foram verificados casos clínicos em indivíduos após realizarem treinamentos. Os dados obtidos sobre a fauna local, associados com achados prévios nessa área da Zona da Mata, apresentam evidências consistentes sobre a manutenção de um ciclo enzoótico, com a ocorrência de surtos periódicos de LTA, posteriores à realização de treinamentos, em áreas correspondentes à Mata Atlântica remanescente e matas secundárias.

Leishmaniose; Insetos Vetores; Psychodidae
As a contribution to the prevention and control of ATL in situations such as that in the CIMNC, it is suggested that military training exercises be planned for periods with lower vector density, that is, from October to January, in order to minimize contact between humans and vectors and avoid or reduce the number of cases, in addition to using individual protective measures such as clothing that covers exposed body areas and distribution of repellent to individuals participating in training in this area.

\section{Contributors}

M. S. Andrade prepared the tables and figures and checked the bibliographic references. H. F. Valença, A. L. Silva, and F. A. Almeida participated exclusively in the sandfly collection fieldwork and species identification in the laboratory. M. E. F. Brito made suggestions on the disease data at the study location and the Leishmania typing, in addition to participating in the laboratory work for isolation of the parasite, together with E. L. Almeida. S. P. Brandão Filho coordinated the study and wrote the article. 


\section{References}

1. Lainson R, Shaw JJ. New World leishmaniasis. The neotropical Leishmania species. In: Collier L, Balows A, Sussman M, editors. Topley \& Wilson's microbiology and microbial infectious diseases. 9th Ed. London: Arnold; 1998. p. 241-66.

2. Desjeux P. The increase in risk factors for leishmaniasis world-wide. Trans R Soc Trop Med Hyg 2001; 95:239-43.

3. Shaw JJ. New World leishmaniasis: the ecology of leishmaniasis and the diversity of leishmanial species in Central and South America. In: Farrell JP, editor. World class parasites: Leishmania. v. 4. Boston: Kluwer Academic Publishers; 2002. p. 1131.

4. Vexenat JA, Barreto AC, Marsden PD. Características epidemiológicas da leishmaniose tegumentar americana em uma região endêmica do Estado da Bahia. III. Fauna flebotomínica. Mem Inst Oswaldo Cruz 1986; 81:293-301.

5. Azevedo ACR, Rangel EF, Costa EM, David J, Vasconcelos AW, Lopes UG. Natural infection of Lutzomyia (Nyssomyia) whitmani by Leishmania of the Braziliensis complex in Baturité, Ceará State, Northeast Brazil. Mem Inst Oswaldo Cruz 1990; 85:251.

6. Ready PD, Ribeiro AL. Presence of Psychodopygus wellcomei: a proven vector of Leishmania braziliensis in Ceará State. Mem Inst Oswaldo Cruz 1983; 78:235-6.

7. Queiroz R, Vasconcelos IAB, Vasconcelos AW, Pessoa FAC, De Sousa RN, David JR. Cutaneous leishmaniasis in Ceara State in northeastern Brazil: incrimination of Lutzomyia whitmani (Diptera: Psychodidae) as a vector of Leishmania braziliensis in Baturité municipality. Am J Trop Med Hyg 1994; 50:693-8.

8. Brandão-Filho SP, Campbell-Lendrum DH, Brito MEF, Shaw JJ, Davies CR. Epidemiological surveys confirm an increasing burden of cutaneous leishmaniasis in north-east Brazil. Trans R Soc Trop Med Hyg 1999; 93:488-94.

9. Brito MEF, Brandão-Filho SP, Salles NRS, Cupolillo E, Grimaldi Jr. G, Momen H. Human cutaneous leishmaniasis due to a new enzymatic variant of Leishmania (Viannia) braziliensis occurring in Pernambuco, Brazil. Mem Inst Oswaldo Cruz 1993; 88:633-4.

10. Brandão-Filho SP. Eco-epidemiologia da leishmaniose tegumentar americana associada a Leishmania (Viannia) braziliensis na Zona da Mata Atlântica do Estado de Pernambuco, Brasil [Tese de Doutorado]. São Paulo: Universidade de São Paulo; 2001.

11. Brandão-Filho SP, Brito MEF, Carvalho FG, Ishikawa EA, Floetter-Winter LM, Shaw JJ. Wild and synanthropic hosts of Leishmania (Viannia) braziliensis in the endemic cutaneous leishmaniasis locality of Amaraji, Pernambuco State, Brasil. Trans R Soc Trop Med Hyg 2003; 97:291-6.
12. Brandão-Filho SP, Brito MEF, Martins CAP, Sommer IB, Valença HF, Almeida FA, et al. Leishmaniose tegumentar americana em centro de treinamento militar localizado na Zona da Mata de Pernambuco, Brasil. Rev Soc Bras Med Trop 1988; 31:575-8.

13. Andrade MS. Epidemiologia da leishmaniose tegumentar americana em centro de treinamento militar na Zona da Mata de Pernambuco, Brasil [Dissertação de Mestrado]. Recife: Centro de Pesquisas Aggeu Magalhães, Fundação Oswaldo Cruz; 2004.

14. Vilela ML, Rangel EF, Lainson, R. Métodos de coleta e preservação de flebotomíneos. In: Rangel EF, Lainson R, organizadores. Flebotomíneos do Brasil. Rio de Janeiro: Editora Fiocruz; 2003. p. 353-67.

15. Young D, Duncan M. Guide to the identification and geographic distribution of Lutzomya sand flies in México, the West Indies, Central and South America (Diptera: Psychodidae). Gainesville: Associated Publishers; 1994.

16. Walton BC, Shaw JJ, Lainson R. Observations on the in vitro cultivation of Leishmania braziliensis. J Parasitol 1977; 63:1118-9.

17. Evans D. Handbook on isolation, characterization, and cryopreservation of Leishmania. Geneva: World Health Organization; 1989.

18. Shaw JJ, Ishikawa EA, Lainson R. A rapid and sensitive method for the identification of Leishmania with monoclonal antibodies using fluorescein-labelled avidin. Trans R Soc Trop Med Hyg 1989; 83:783-4.

19. Cupolillo E, Grimaldi Jr. G, Momen H. A general classification of New World Leishmania using numerical zymotaxonomy. Am J Trop Med Hyg 1994; 50:296-11.

20. Marzochi MCA. Leishmanioses no Brasil: as leishmanioses tegumentares. J Bras Med 1992; 63:82104.

21. De Souza A, Ishikawa E, Braga R, Silveira F, Lainson R, Shaw JJ. Psychodopygus complexus, a new vector of Leishmania braziliensis to humans in Pará State, Brazil. Trans R Soc Trop Med Hyg 1996; 90:112-3.

22. Campbell-Lendrum DH, Brandão-Filho SP, Ready P, Davies CR. Host and/or site loyalty of Lutzomyia whitmani (Diptera: Psychodidae) in Brazil. Med Vet Entomol 1999; 13:209-11.

23. Marzochi MCA, Marzochi KBF. Tegumentary and visceral leishmaniasis in Brazil: emerging anthropozoonoses and possibilities for their control. Cad Saúde Pública 1994; 10 Suppl 2:359-75.

Submitted on 31/Aug/2004

Final version resubmitted on $04 / \mathrm{Jan} / 2005$

Approved on 06/Jan/2005 